$\frac{10}{512192} 850$

SANDIA REPORT

SAND95-8001 • UC-402

Unlimited Release

Printed October 1994

M97052834

\title{
Environmental Protection Implementation Plan
}

D. D. Brekke

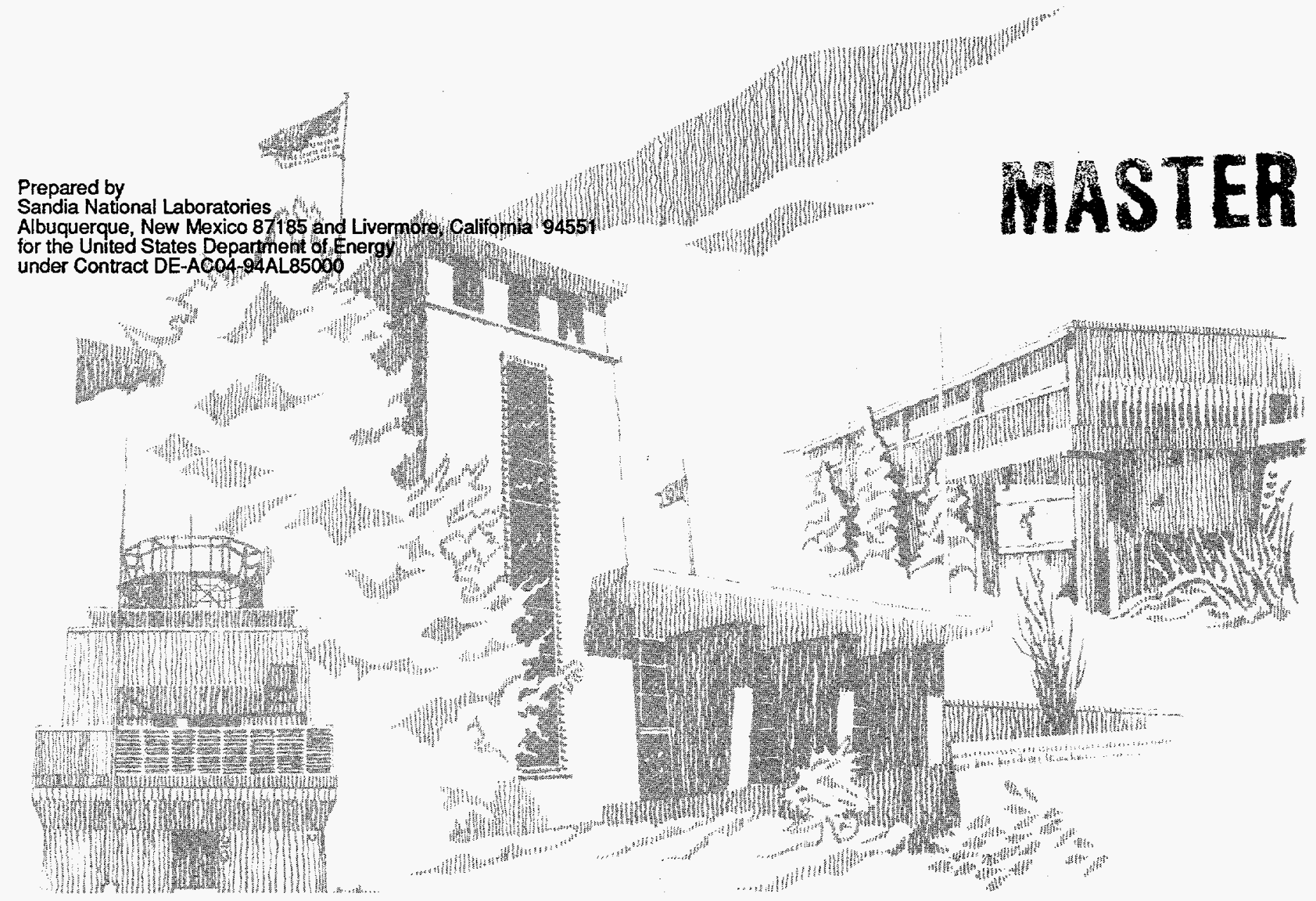


Issued by Sandia National Laboratories, operated for the United States Department of Energy by Sandia Corporation.

NOTICE: This report was prepared as an account of work sponsored by an agency of the United States Government. Neither the United States Government nor any agency thereof, nor any of their employees, nor any of the contractors, subcontractors, or their employees, makes any warranty, express or implied, or assumes any legal liability or responsibility for the accuracy, completeness, or usefulness of any information, apparatus, product, or process disclosed, or represents that its use would not infringe privately owned rights. Reference herein to any specific commercial product, process, or service by trade name, trademark, manufacturer, or otherwise, does not necessarily constitute or imply its endorsement, recommendation, or favoring by the United States Government, any agency thereof or any of their contractors or subconractors. The views and opinions expressed herein do not necessarily state or reflect those of the United States Government, any agency thereof or any of their contractors or subcontractors.

This report has been reproduced from the best available copy.

\section{Available to DOE and DOE contractors from:}

Office of Scientific and Technical Information P. O. Box 62

Oak Ridge, TN 37831

Prices available from (615) 576-8401, FTS 626-8401

Available to the public from:

National Technical Information Service

U.S. Department of Commerce

5285 Port Royal Rd.

Springfield, VA 22161 


\section{DISCLAMMER}

Portions of this document may be illegible in electronic image products. Images are produced from the best available original document. 
SAND95-8001

UC-402

Unlimited Release

Printed October 1994

\title{
ENVIRONMENTAL PROTECTION \\ IMPLEMENTATION PLAN
}

\author{
David D. Brekke
}

Sandia National Laboratories/California

\begin{abstract}
This Environmental Protection Implementation Plan is intended to ensure that the environmental program objectives of Department of Energy Order 5400.1 are achieved at SNL/California. The Environmental Protection Implementation Plan serves as an aid to management and staff to implement new environmental programs in a timely manner.
\end{abstract}




\title{
SANDIA NATIONAL LABORATORIES/CALIFORNIA
}

\section{ENVIRONMENTAL PROTECTION IMPLEMENTATION PLAN}

\author{
For the Period: \\ November 9, 1994 to November 9, 1995 \\ Prepared: October 1994
}

Prepared by: Environmental Protection Department, 8642

Environmental Operations Department, 8644

Sandia National Laboratories/California

P. O. Box 969 , MS 9222

Livermore, CA 94551-0969

Approved by:

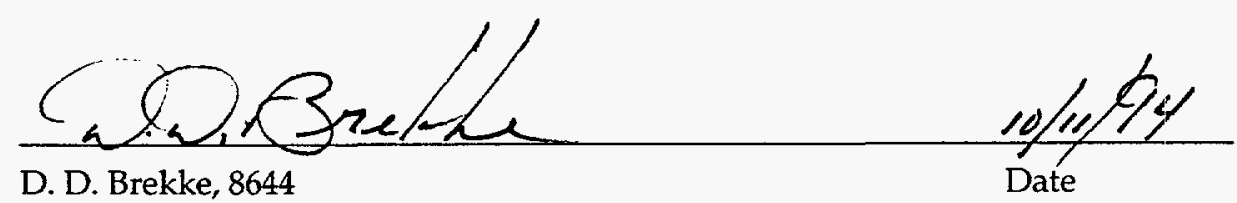

D. D. Brekke, 8644

Environmental Monitoring Program

Environmental Operations Department

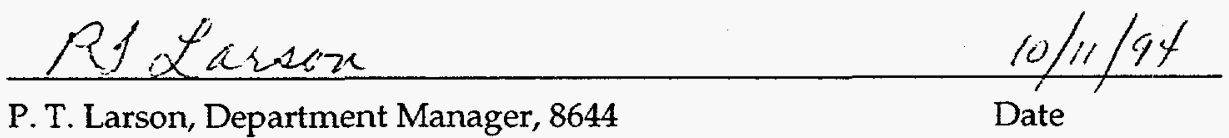

Environmental Operations Department

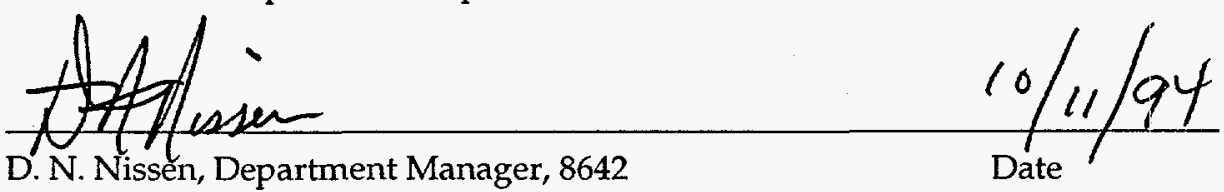

Enviropmental Protection Department

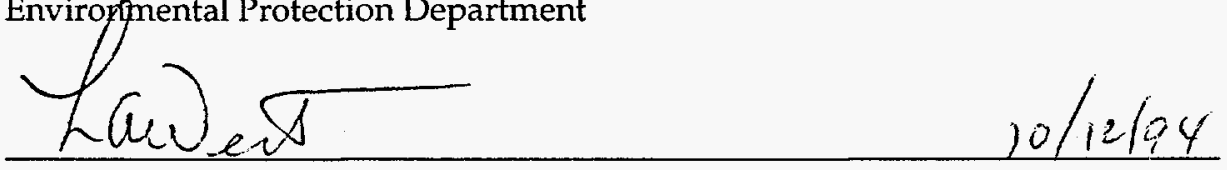

L. A. West, Director, 8600

Date

ES\&H, Facilities and Security Center

$\operatorname{mes} 9 x+210 / 94$

J. C. Crawford, Vice President, 8000

Date

Sandia National Laboratories, California 


\section{CONTENTS}

Page

1.0 Introduction ............................................................................................................................................

1.1 Site Description ................................................................................................................................................

1.2 Environmental Protection Policies............................................................................................................10

1.3 Environmental ALARA ...................................................................................................................................11

1.4 Environment, Safety, and Health Organization ……...............................................................................11

1.5 Environmental Protection Responsibilities ..............................................................................................17

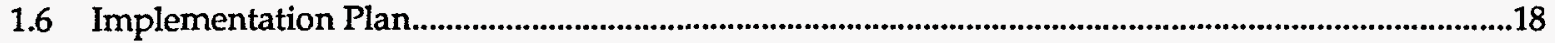

1.7 Schedule for DOE Order 5400.1 ...............................................................................................................20

2.0 Notification of Environmental Occurrences .............................................................................21

2.1 Notification Procedures.................................................................................................................................21

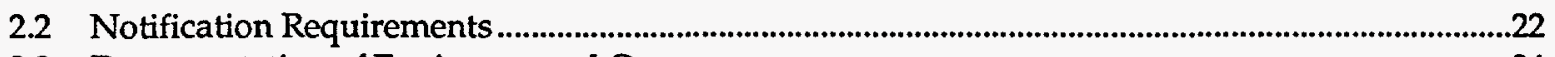

2.3 Documentation of Environmental Occurrences ....................................................................................24

2.4 Effluent Information System Report........................................................................................................25

3.0 General Planning and Reporting .........................................................................................................26

3.1 Long-range Environmental Protection Plan...............................................................................................2.

3.2 Annual Site Environmental Report ......................................................................................................26

3.3 OMB Circular A-106.........................................................................................................................27

4.0 Special Programs and Plans............................................................................................................28

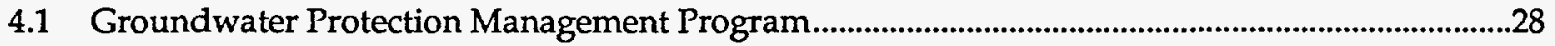

4.2 Waste Minimization and Pollution Prevention Awareness Program …………...................................28

5.0 Environmental Monitoring Program ...................................................................................................32

5.1 Effluent Monitoring ……………………...............................................................................................32

5.2 Environmental Surveillance.........................................................................................................................32

5.3 Environmental Monitoring Plan ..................................................................................................................33

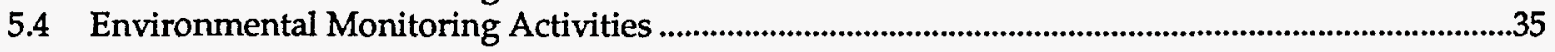

6.0 Quality Assurance and Data Verification .......................................................................................36

6.1 Quality Assurance Program ......................................................................................................................36

6.2 Laboratory Certification .............................................................................................................................36

6.3 DOE Laboratory Quality Assurance Program for Radioactive Materials...............................................37

6.4 Independent Data Verification .........................................................................................................................

7.0 References .............................................................................................................................................38

Acronyms and Abbreviations ............................................................................................................................39

Figures and Tables

Figure 1 SNL/California site map..............................................................................................................

Figure 2 SNL/California in a regional setting..................................................................................................9

Figure 3 SNL/California Environment, Safety, and Health organizational chart ...........................................12

Figure 4 SNL/California Environmental Protection Department,

Org. 8642, organizational chart . .13

Figure 5 SNL/California Environmental Operations Department, Org. 8644, Organizational Chart ...........................................................................................................14

Table 1 SNL/California's DOE Order 5400.1 Compliance Schedule ……………………................................20 


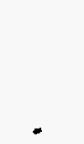




\subsection{INTRODUCTION}

Sandia National Laboratories (SNL) is a prime contractor to the Department of Energy (DOE). On October 1, 1993, Martin Marietta Corporation assumed the contract to manage and operate SNL. SNL consists of facilities in Albuquerque, NM; Livermore and San Jose, CA; Tonopah, NV; and Kauai, HI.

As one of the United States' multipurpose national laboratories, SNL develops solutions to a wide range of problems facing the country. SNL's mission includes advanced military technology, energy and environmental research, arms control/nonproliferation, and advanced manufacturing technology. In addition, Sandia is actively pursuing the transfer of commercially viable technology to the private sector to strengthen our nation's economic competitiveness in world markets. Operations at SNL's California facility in Livermore comprise four broad programmatic areas:

National Security: This program involves national security work, both nuclear and nonnuclear. Defense activities encompass maintenance of the nuclear weapons stockpile, nuclear weapons development, control of the proliferation of nuclear weapons, and aerospace research.

Manufacturing Integration: This program uses the systems and technology at the site to enhance the nation's economic competitiveness. Our aim is to be an agile manufacturing test bed for low-cost prototypes and development, as needed by U.S. industries. This program serves as a focus for partnerships with U.S. companies to develop joint manufacturing solutions.

Energy and Environment: This multifunctional program addresses a broad range of initiatives centered on combustion science and technology. Areas of emphasis include combustion processes, sensor technology, modeling, incinerator processes, and global climate change.

California Initiatives: This program works with California industries to address problems facing the nation, such as transportation, manufacturing, and the environment.

SNL/California incorporates the highest regard for environment, safety, and health (ES\&H) into every experiment and all site operations. The site operates under the scope of Federal, State, and local regulatory authorities and has obtained all appropriate operating permits. SNL is committed to operating in full compliance with the letter and spirit of applicable environmental laws, regulations, and standards. Furthermore, SNL/California strives to go beyond compliance with legal requirements by making every effort practical to reduce impacts to the environment to levels as low as reasonably achievable.

\subsection{Site Description}

The SNL/California site (Fig. 1) covers $1.7 \mathrm{~km}^{2}$ (413 acres) of land located on the southeastern boundary of the City of Livermore, in eastern Alameda County, $65 \mathrm{~km}$ ( 40 miles) east of San Francisco (Fig. 2). The site lies at the western base of the Altamont Hills, which form the eastern boundary of the Livermore Valley. 


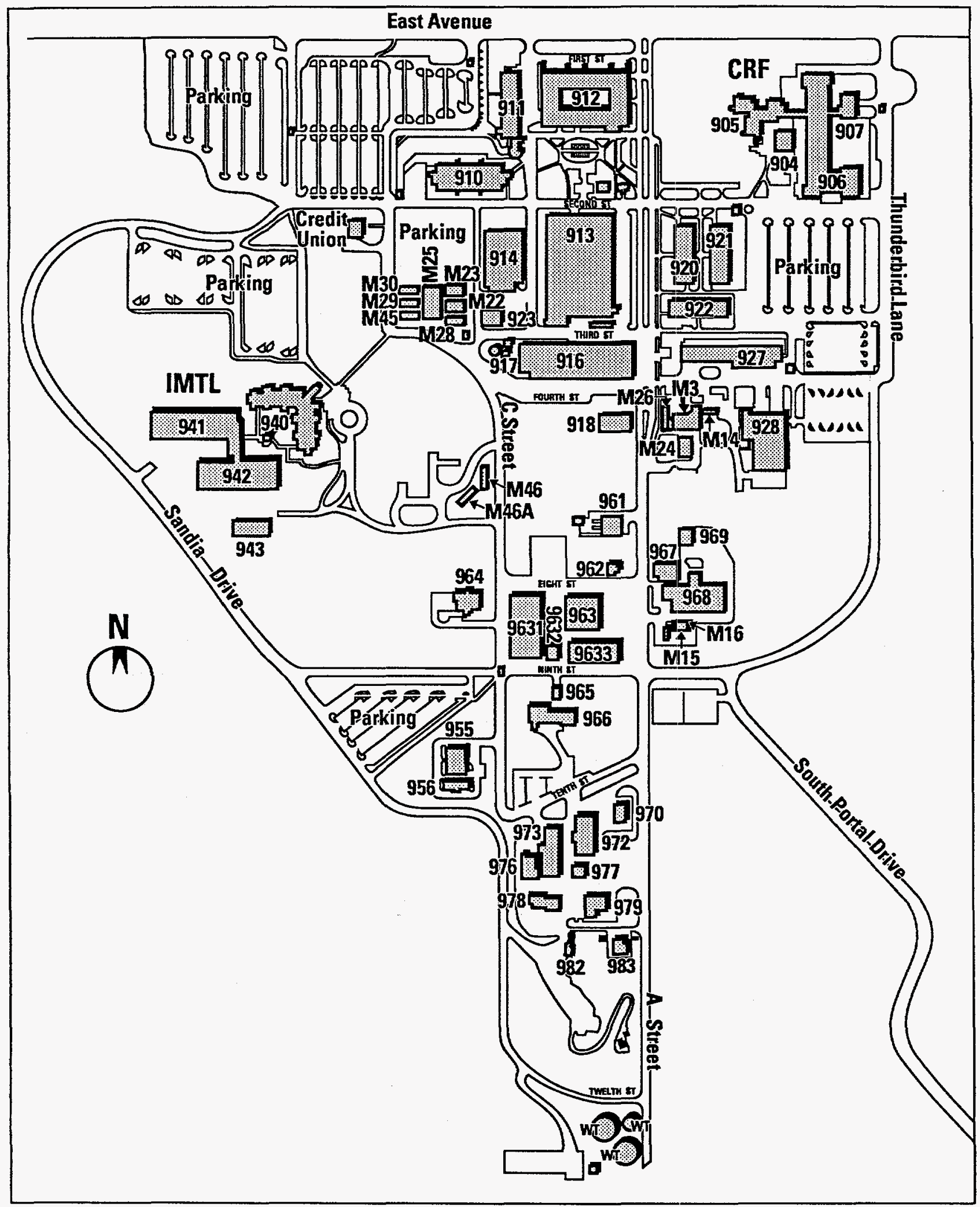

Figure 1. SNL/Califomia site map. 


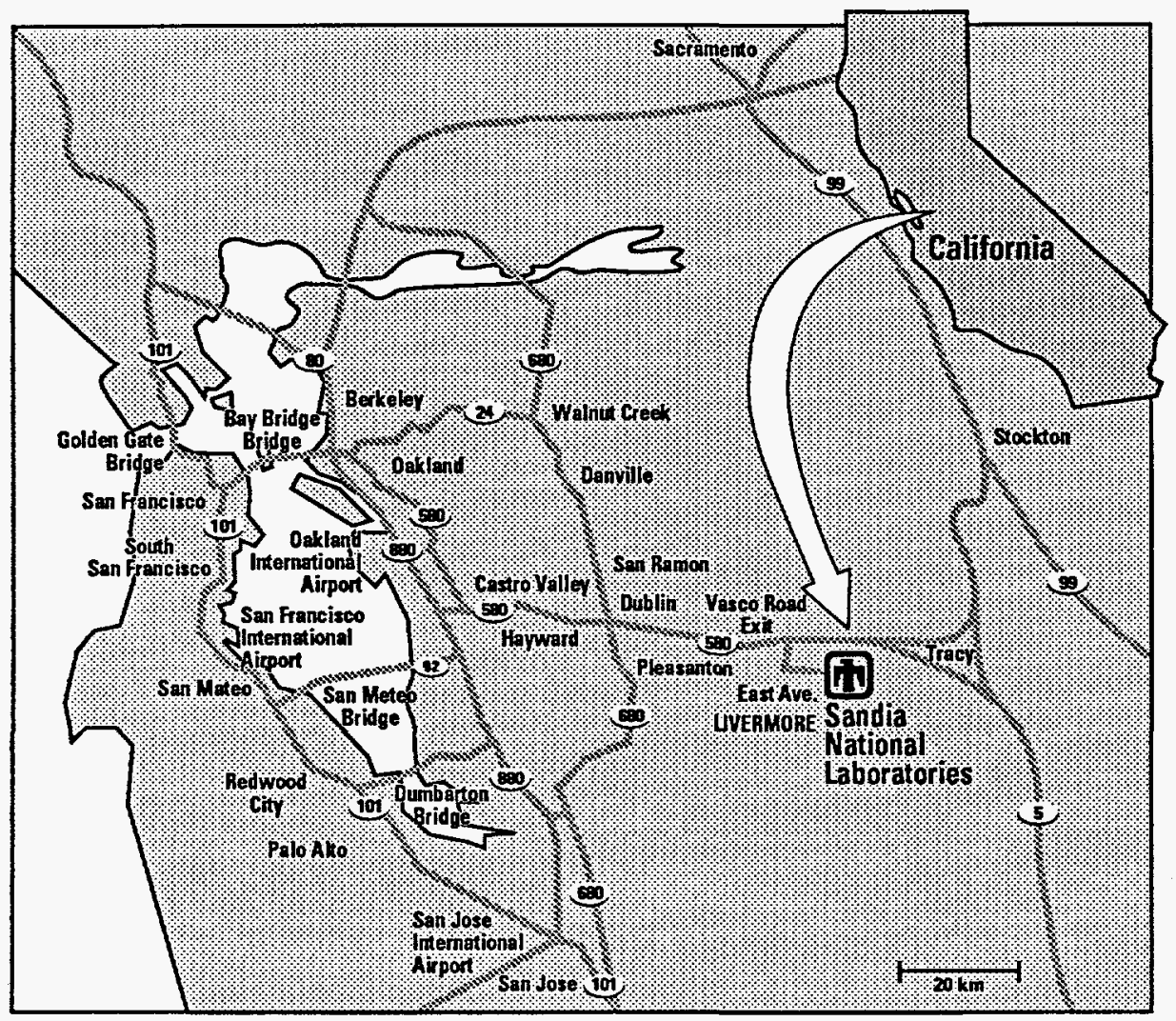

Figure 2. SNL/California in a regional setting.

The Livermore Valley is an irregularly shaped lowland in the Diablo Range of the California Coastal Mountain Range. The valley is approximately $26 \mathrm{~km}$ ( 16 miles) long (east to west) and averages about $11 \mathrm{~km}$ ( 7 miles) wide. The valley floor slopes downward generally to the west at about $10 \mathrm{~m} / \mathrm{km}$ ( $50 \mathrm{ft}$. $/$ mile). The elevation is approximately $200 \mathrm{~m}$ $(660 \mathrm{ft}$.) at the eastern boundary of the valley and $90 \mathrm{~m}(295 \mathrm{ft}$.) at the southwest corner.

The Valley's major drainage is intermittent streams (arroyos). These arroyos generally carry water to the southwest end of the Valley and into the Alameda Creek near Sunol. Alameda Creek then continues on to the San Francisco Bay. 


\subsection{Environmental Protection Policies}

Sandia National Laboratories, as part of the DOE Complex, is committed to full compliance with all applicable environmental laws and regulations. This Environmental Protection Implementation Plan (EPIP) is intended to ensure that the environmental program objectives of DOE Order 5400.1 are achieved at SNL/California. ${ }^{1}$ The EPIP serves as an aid to management and staff to implement these programs in a timely manner. SNL's ES\&H policy, as stated in the SNL ESEH Manual, is as follows:2

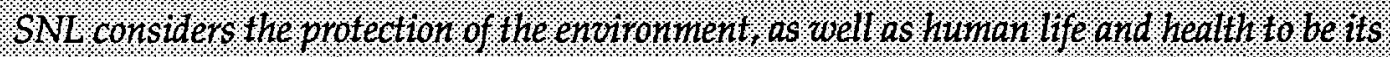
top priority. Conflicts between ESEH requirements and other programintic needs will be. resolved to fully meet the ESEH requirements. Accordingly. SNL siall design prodicts and: conduct operations with the highest regard for the protection and preservation of the environ. inent and safety and health of its personnel, contractors, and the public. SNL. shall ensure thie. occupational health and safety of SNI personnel, as well as environmental protection and preservation throughout all operations by complying with applicable federal, state, and local laws and regulations, DOE Orders, permit agreements, orders, and consent decrees. SNL shall make sure that contractors and site visitors are fully informed of this Policy and of their. obligation to comply with it. In addition, SNL shall continuously evaliate regulatory require. ments, corporate polictes, and customer needs, and shall adjust its operations to meet these changing needs through the Sandia Quality Improvement Plan. This inclides a 80 al of cont. tinuous improvement in ESEH processes.

Concerns and conduct in matters pertaining to the environment, safety, and health are the responsibility of all SNL employees, on site contractors and visitors. NO IOB IS MORE: IMPORTANT THAN YOUR HEALTH, YOUR SAFETY AND THE PROTECTION OF OUR ENUIRONMENT.

Primary responsibility for assuring compliance with ES\&H principles and procedures rests with line managers and those in charge of specific programs and experiments. To support line managers in fulfilling this responsibility, Sandia maintains a staff of ES\&H professionals.

Long-standing DOE policy states that sites will comply with all applicable environmental statutes and regulations. On September 6, 1990, the DOE signed an Agreement in Principle (AIP) with the State of California to provide California's citizens independent assurance that DOE sites in California are fulfilling their commitments to health, safety, and the environment. The AIP is part of a DOE effort to conduct operations with openness and full disclosure to the local community. To implement the AIP, the DOE has agreed to provide the State access to its facilities, comprehensive monitoring data, and financial support. As deemed necessary, the State will independently monitor and oversee SNL operations in California. 


\subsection{Environmental ALARA}

DOE Orders require that risks to the public and the environment be kept as low as reasonably achievable (ALARA). This aim is an essential part of corporate good citizenship and an element by which the quality of the Laboratories is judged.

ALARA Program Implementation specifies the formation of an ALARA Committee. ${ }^{3}$ SNL/California's ALARA Committee comprises representatives from the Health Protection Department, the Environmental Operations Department, the Component Technology Department, the Test Assembly Group, the Materials Technology Department, and the Physical Science Department. This committee directs line management to establish annual ALARA goals. These goals include the total radioactivity released to the environment in airborne and liquid effluents.

The ALARA Committee is also responsible for reviewing Facilities Management designs. Review includes technical, economic, practical, and public policy issues. The review process is formalized in an implementing procedure.

Another method by which ALARA concerns may be brought to the committee's attention is the National Environmental Policy Act (NEPA) review process. All major construction projects, changes in operations, and proposed new operations must be evaluated according to NEPA criteria. SNL/California has a formal NEPA review process. They are done by the NEPA Compliance Officer, in the Environmental Operations Department. The NEPA Compliance Officer is responsible for obtaining information from other organizations in the ES\&H, Facilities and Security Center, as appropriate. The NEPA Compliance Officer will forward all documentation of projects with potential radiological impacts on the public or the environment to the ALARA Committee for review.

\subsection{Environment, Safety, and Health Organization}

At SNL, ES\&H is every employee's responsibility. ES\&H management combines technical experts (who are educated and/or experienced in specific ES\&H fields) with line personnel to implement ES\&H requirements throughout the Laboratories. An SNL Quality Leadership Council meets regularly to establish ES\&H policy related issues affecting the entire company.

To fulfill its ES\&H commitments, SNL has established a corporate-level ES\&H organization. This resides in the Laboratory Services Division at SNL/New Mexico. The ES\&H requirements are implemented using written ES\&H programs and procedures.

SNL/California has an ES\&H organization to carry out the corporate ES\&H vision. Its organizational structure is shown in Fig. 3. This organization develops and implements ES\&H programs and ensures compliance with regulations specific to the California site.

To help assure ES\&H commitments are fulfilled, SNL/California has established a site ES\&H Council (SCEC) and a Management Assurance Department (see sections 1.4.4 and 1.4.5). 
Figure 3. SNL/Califomia Environment, Safety, and Health organizational chart.

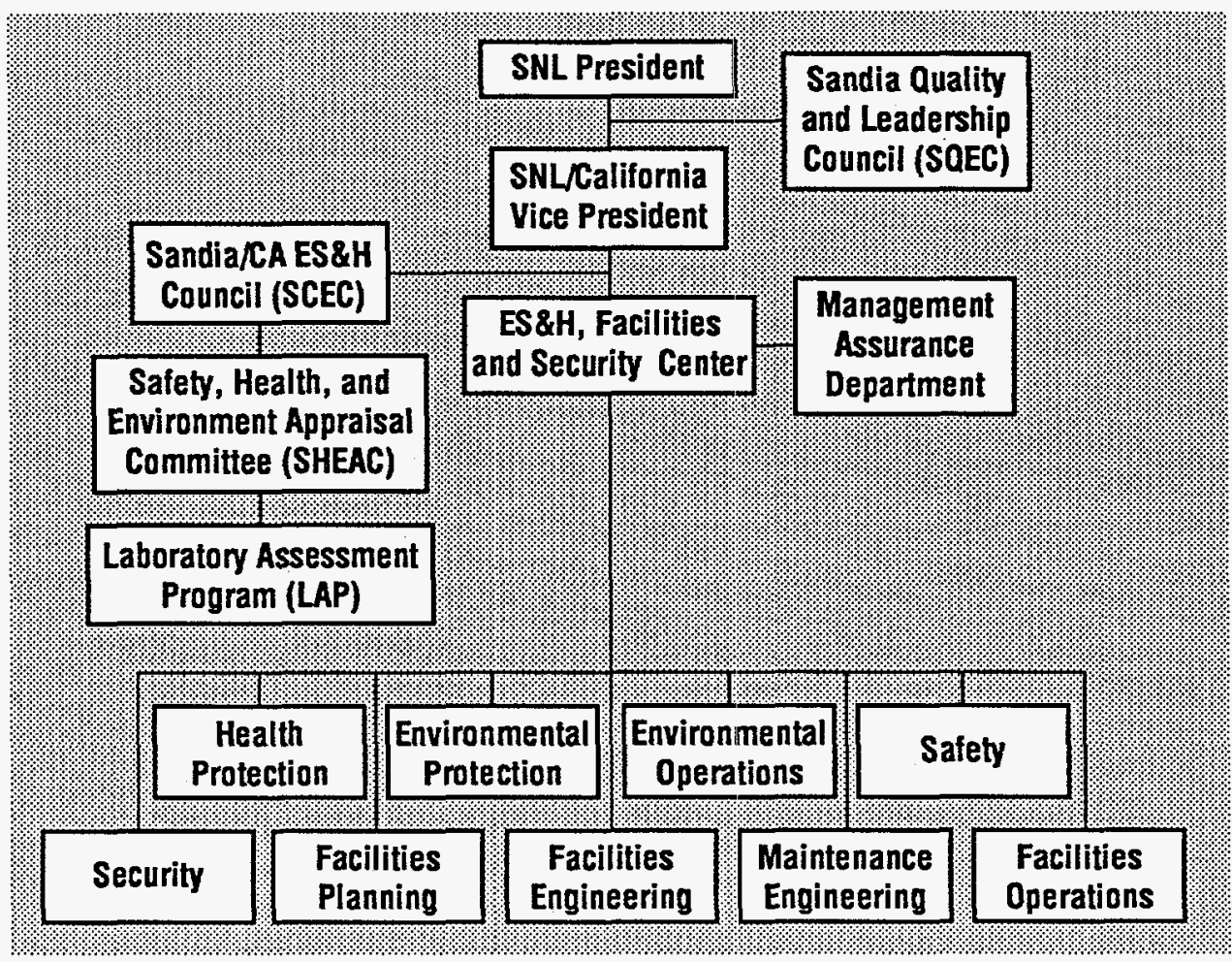

\subsubsection{ES\&H, Facilities and Security Center}

The ES\&H, Facilities and Security Center is responsible for ES\&H at the SNL/California site. An important part of the center's mission is to ensure the health and safety of SNL/California employees and the general public, and to protect the environment. This mission is fulfilled by helping SNL/California employees understand and comply with DOE Orders and their legal responsibilities under Federal, State, and local laws and regulations. The ES\&H, Facilities and Security Center has four departments involved in ensuring workplace safety and protection of the environment: Health Protection, Environmental Operations, Environmental Protection, and Safety. An ES\&H and facilities quality assurance group reports directly to the center director and is functionally independent of the departments within the center.

The environmental base programs at SNL/California are consolidated in the Environmental Protection and Environmental Operations departments, which are responsible for this plan. Therefore, the functions of these departments are described below.

\subsubsection{Environmental Protection Department}

The Environmental Protection Department has a variety of programs to properly manage (minimize and dispose of) hazardous, low-level radioactive, and mixed wastes and to assess and restore potentially contaminated areas. To fulfill its mission, the department has groups responsible for waste management, environmental assessment and restoration, and waste minimization/pollution prevention (Fig. 4). The following sections briefly describe the activities of these groups. 


\section{Waste Management}

The Waste Management Group manages hazardous, radioactive, energetic, medical, and mixed wastes. Responsibilities include picking up, transporting, storing, and disposing of (off-site) wastes in accordance with DOE, EPA, and State regulations. The Waste Management Group is also responsible for employee training in hazardous waste generation, disposal, and spill control and remediation. The only waste treatment processes done on-site are compaction (to reduce waste volume), consolidation and commingling. No transuranic or high-level waste is generated at this site. No hazardous waste has ever been disposed of on-site by SNL/California. This group also does pollution prevention opportunity assessments for major hazardous waste generators, with the goal of reducing hazardous waste generation.

\section{Environmental Assessment and Restoration}

The Environmental Assessment and Restoration Group is responsible for assessing the extent of historical contamination of SNL/California sites and managing any necessary restoration efforts. This group also is responsible for characterizing groundwater flow and groundwater monitoring.

The group fulfills SNL/California's responsibilities under the Comprehensive Environmental Response, Compensation, and Liability Act (CERCLA) and the underground storage tank program.

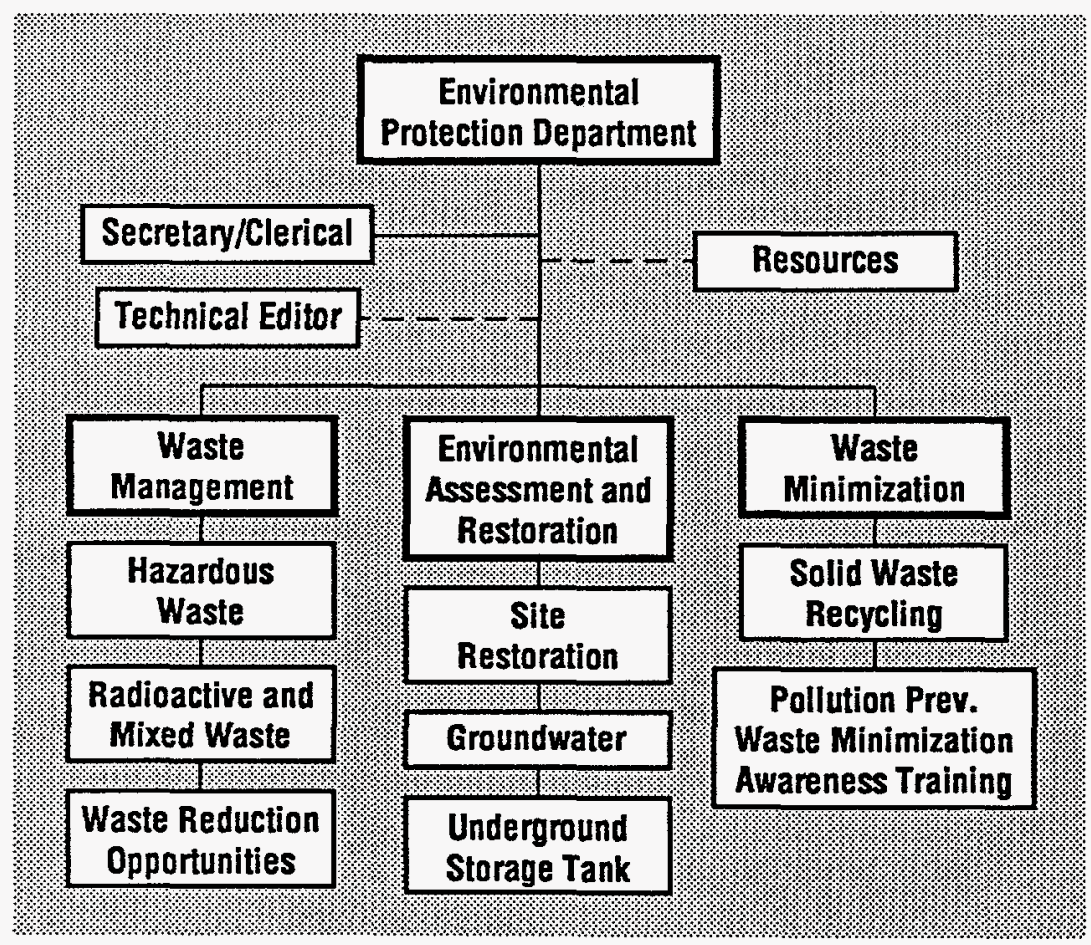

Figure 4. SNL/Califormia, Environmental Protection Department organizational chart. 


\section{Waste Minimization}

The Waste Minimization Group promotes the reduction of waste generated by site operations as much as possible. It coordinates source reduction and recycling. It represents an ongoing effort to make pollution prevention part of Sandia's operating philosophy. SNL/California has appointed a waste minimization coordinator to manage the Waste Minimization/Pollution Prevention Awareness Program. The coordinator also is responsible for program planning and employee awareness training in waste reduction and minimization methods.

\subsubsection{Environmental Operations Department}

The Environmental Operations Department is responsible for ensuring that SNL/California operations have a minimal impact on the environment. The department provides guidance and assistance to line programs to comply with applicable environmental regulations and DOE Orders. A staff of professionals provides consultation, safety reviews, and evaluations for the California site. The department maintains a variety of programs to monitor the impacts of site emissions and to preserve the quality of the environment. To fulfill its mission, the department has groups responsible for environmental monitoring, air quality, environmental technologies, information systems support, and NEPA implementation (Fig. 5). The following sections briefly describe the activities of these groups.

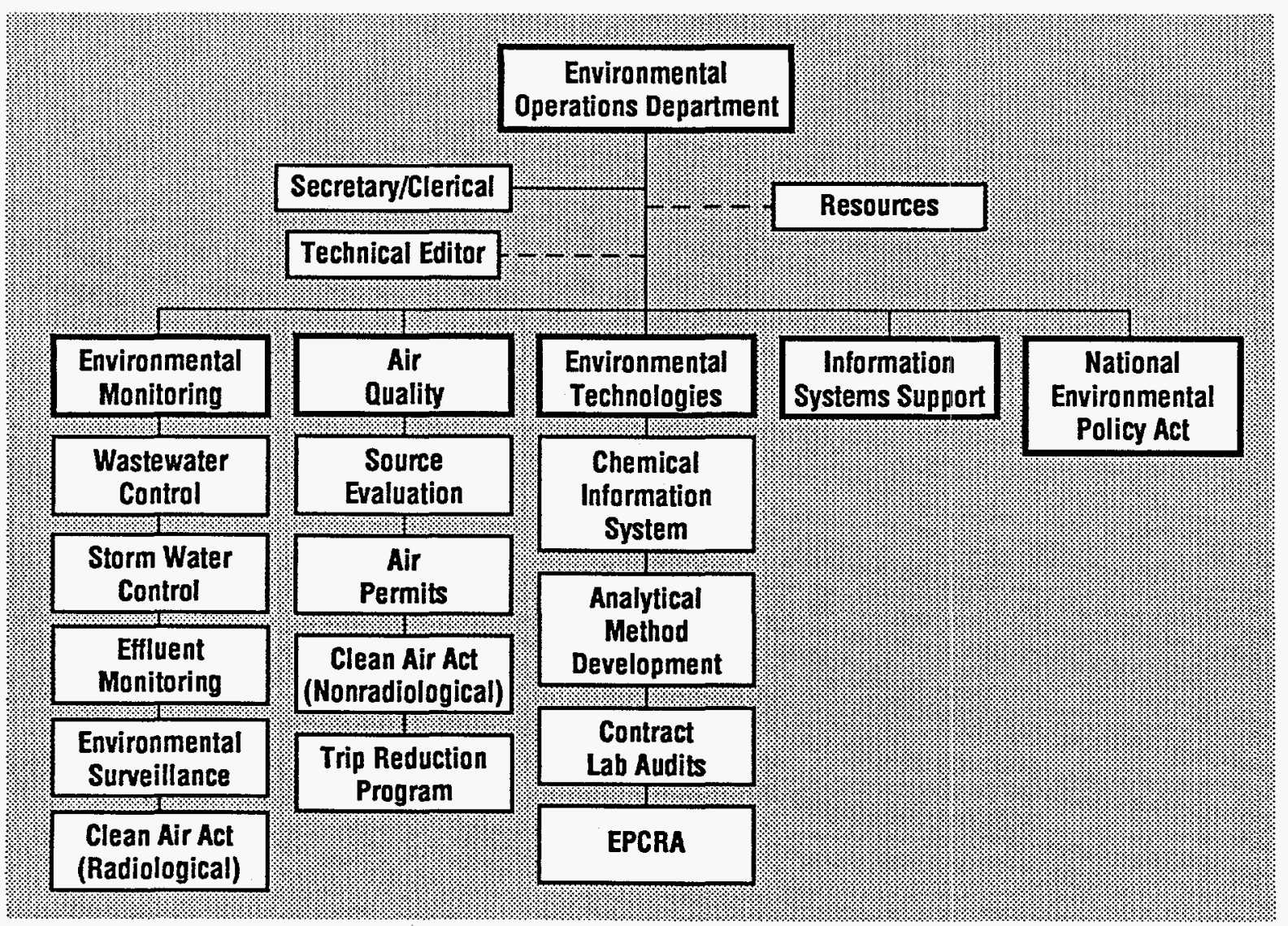

Figure 5. SNL/Califomia, Environmental Operations Department organizational chart. 


\section{Environmental Monitoring}

The Environmental Monitoring Group verifies that SNL/California complies with all Federal, State, and local regulations and DOE Orders governing emissions to the environment. The group monitors ambient air, wastewater and storm water discharges, and the general environment of the Laboratory and vicinity to verify compliance with established safety standards. The group prepares compliance reports, permit applications, and other documents to demonstrate compliance with various environmental regulations and DOE Orders. The group also provides consultation and training to the line organizations on issues concerning discharges to the atmosphere, storm drainage system, and sanitary sewer.

\section{Air Quality}

The Air Quality Group is responsible for the regulatory compliance of all air emission sources at the SNL/California site. This group does the following:

- updates the site air emissions inventory,

- evaluates Sandia operations that are potential sources of air pollutants,

- determines and documents compliance requirements,

- maintains compliance records,

- prepares reports and permit applications required by air quality regulations, and

- manages the Trip Reduction Program, which surveys employee/contractor transportation methods and educates employees and contractors on transportation alternatives.

The Air Quality Group also works with managers to formulate strategies to achieve compliance with applicable air emissions regulations.

\section{Environmental Technologies}

The Environmental Technologies Group is responsible for a wide range of environmental support activities. These include development of a site-wide chemical information management system and auditing of contract laboratories. This system is designed to help SNL/California more effectively comply with Federal and State regulations and DOE Orders. It is a database, which tracks chemical containers in facilities by bar-code labels. It provides detailed information to several programs:

- Employee Right-to-Know,

- Emergency Planning and Community Right-to-Know,

- Waste Minimization,

- Spill Information and Emergency Preparedness,

- Fire Protection, and

- California Proposition 65 Compliance.

This system also maintains the site Material Safety Data Sheet (MSDS) library and can supply MSDSs on-line. 


\section{Information Systems Support}

The Information Systems Support Group is responsible for centralizing data management and computer system support activities in the Environmental Protection and Environmental Operations departments. These interdepartmental activities include the following:

- implementation and support of information systems,

- consultation on computer hardware and software selection,

- management of network communications,

- monitoring of data flow between programs, and

- the design of improved methods for implementing new information systems and procedures.

\section{National Environmental Policy Act (NEPA) Implementation}

The NEPA Implementation Group evaluates proposed projects, activities, and programs for compliance with NEPA. NEPA requires that SNL/California review these projects, activities, and programs for potential environmental and human impact. Key environmental concerns include potential air emissions (through vents or stacks on buildings), water effluents (storm water, drinking water, or sewer outfall), human exposure to hazardous substances, and waste generation and minimization.

\subsubsection{SNL/California Management Assurance Department}

The Management Assurance Department provides the methods for internal organizations to conduct self-appraisals. It helps line organizations with self-assessment activities to assure that the site is fulfilling its ES\&H responsibilities. The Management Assurance Department tracks audit findings and is developing a trend analysis program in partnership with SNL/New Mexico.

\subsubsection{SNL/California Vice Presidential ES\&H Council}

The Vice Presidential ES\&H Council (SCEC) is chaired by the SNL/California Vice President. It includes the directors of the line organizations (centers) and SNL/California ES\&H coordinators. The SCEC ensures top-level management involvement in developing and monitoring ES\&H goals. It establishes, promotes, and communicates a culture that recognizes ES\&H as a top priority at the California site. The SCEC also provides leadership and consistency of approach in the California ES\&H program. It provides a mechanism for organizational communication-both horizontally and vertically.

\subsubsection{Self-Assessment Program}

SNL has a comprehensive system to assess and track ES\&H commitments. The Sandia ES\&H Self-Assessment Program consists of three key sub-programs: Appraisal, Performance Indicators, and Operating Experience Evaluation.

The ES\&H Appraisal Program establishes an internal appraisal hierarchy consisting of independent appraisals, management surveillance, and line inspection activity. The inde- 
pendent appraisals are done under the auspices of ES\&H Assessment Department (SNL/New Mexico), which also provides the SNL tracking and lessons learned functions. SNL/California has established the Laboratory Assessment Program to conduct site-wide independent inspections.

The ES\&H Performance Indicator Program establishes a set of quantitative measures for the DOE to evaluate and track the Laboratories' ES\&H performance. Line self-assessment is provided principally by the Management Surveillance Program, supplemented by line inspection activity as deemed necessary by line management.

The ES\&H Operating Experience Evaluation Program documents incidents and lessons learned from these incidents. This information is distributed to employees to heighten their awareness of ES\&H principles. In addition, SNL/California's ES\&H Quality Assurance Group coordinates quality assurance/technical assessments within SNL/California's ES\&H organization.

\subsection{Environmental Protection Responsibilities}

This section describes the organizations and individuals responsible for ensuring compliance with DOE Order 5400.1. ${ }^{1}$ Compliance includes incorporating the thirteen responsibilities required of the Head of the Field Organization, as identified in the Order [pgs. 12-14, paragraphs f.(1)-f.(13)]. Each responsibility is listed below in the context of how SNL/California fulfills that responsibility.

1. The SNL Quality Leadership Council and the SNL/California ES\&H Council are responsible for issuing environmental policy statements and goals.

2. Line organizations, with the help of the Environmental Operations and Environmental Protection departments, are responsible for ensuring that all SNL/California operations comply with applicable environmental laws and regulations.

3. The ES\&H coordinators and the Environmental Operations and Environmental Protection departments facilitate implementation of the ES\&H programs.

4. The Environmental Operations and Environmental Protection departments are responsible for coordinating the receipt and renewal of all required environmental permits for SNL/California operations.

5. The Livermore Assessment Program (with line participation) is responsible for conducting internal environmental appraisals of SNL/California programs, projects, and facilities in accordance with DOE Order 5482.1B and other ES\&H requirements. 4

6. The Environmental Operations and Environmental Protection departments are responsible for establishing and maintaining liaison with appropriate Federal, regional, State, and local environmental officials to facilitate effective environmental management. This communication with regulatory agencies is conducted in accordance with the protocols established by the 
DOE Albuqerque Operations Office (DOE/AL), Kirtland Area Office (DOE/KAO).

7. The ES\&H, Facilities and Security Center is responsible for working with the Procurement Services Department to:

a. develop and implement programs that direct contractors to execute environmental protection compliance programs; and

b. provide oversight, confirmation, and independent verification of these contractor programs.

8. The Environmental Operations and Environmental Protection departments are responsible for preparing long-range environmental protection plans.

9. The ES\&H, Facilities and Security Center is responsible for ensuring that budget requests provide for required environmental protection upgrades and that corrective actions are consistent with the Office of Management and Budget (OMB) Circular A-106 report. 5

10. The Environmental Operations and Environmental Protection departments are responsible for oyerseeing the preparation of the semiannual pollution abatement plans required by the OMB Circular A-106 report. 5

11. The Environmental Operations and Environmental Protection departments are responsible for providing DOE Headquarters (DOE/HQ) all environmental information and documentation requested by the DOE.

12. Any SNL employee has the authority and the responsibility to curtail or suspend any operation that poses a clear and present danger to members of the public or the environment.

13. The ES\&H, Facilities and Security Center and the Public Relations Office are responsible for providing public information and educational programs concerning SNL/California's environmental protection programs.

\subsection{Implementation Plan}

ES\&H concerns are built into programs from planning to completion. Projects are reviewed by the appropriate authorities-the NEPA coordinator, the Health Physics Group, the Environmental Monitoring Group, and the Waste Minimization/Pollution Prevention Group. The aim is to reduce risks to employees, the public, and the environment to the lowest reasonable levels. The procedures used to implement ES\&H requirements are identified below.

\subsubsection{Early Planning}

In conjunction with the requirement for NEPA review, plans for projects, processes, tests, and facilities are submitted for review to the ES\&H, Facilities and Security Center during the conceptual stage. This procedure assures that all risks are considered, controls or miti- 
gation of all hazards are planned, pollution prevention and waste minimization are considered, and Standard Operating Procedures (SOPs) are prepared and approved before operations begin. To assure that new operations, procedures, and facilities work as intended, ES\&H concerns are addressed early in the planning stages.

\subsubsection{Manager Responsibilities}

Managers have the following responsibilities:

1. Participate as a member of the SCEC (as required);

2. Implement the SNL ES\&H policy and programs, establish appropriate procedures within their departments, and communicate SNL's ES\&H policy and expectations to all employees;

3. Identify and assign department staff to implement the ES\&H programs and procedures within the organization;

4. Approve Preliminary Hazard Assessments, Qualitative Risk Assessments, ES\&H SOPs and corrective action reports;

5. Set ES\&H goals for the department and the metrics used to measure progress toward those goals;

6. Establish a manager-led self-appraisal activity-participate in management and functional appraisals of facilities and project activities;

7. Perform management surveillance of all facilities or project activities within the department at least semiannually;

8. Hold a department meeting semiannually to discuss ES\&H performance with respect to the metrics to draw out employees' ES\&H concerns or issues; and

9. Maintain ES\&H documentation, including the ESEH Manual and the Management Assurance Notebook.

\subsubsection{Employee Training}

Department managers are responsible for making sure that all employees and contractors are trained appropriately in ES\&H. The ES\&H Training Group (in the Diversity and Development Department) designs, develops, and presents all Laboratory-wide ES\&H training for employees, contractors, and visitors. As needed, the ES\&H Training Group may request assistance from line organizations or contractors with acknowledged expertise. This assistance may include developing qualification guidelines for instructors. The ES\&H Training Group also maintains the control database of ES\&H training records. 


\subsection{Schedule for DOE Order 5400.1}

Table 1 contains SNL/California's schedule for complying with the reporting requirements of DOE Order 5400.1.1

Table 1. SNL/California's DOE Order 5400.1 Compliance Schedule.

\begin{tabular}{|c|c|c|}
\hline Report/Plan & Due Date & Review/Update \\
\hline Implementation Plan & $11 / 9 / 89$ & none/annual \\
\hline OMB Circular A-106 & $\begin{array}{c}\text { semiannual } \\
(5 / 1 \text { and } 12 / 15)\end{array}$ & none/semiannual \\
\hline Site Environmental Report & annual $(6 / 1)$ & none/annual \\
\hline $\begin{array}{l}\text { Groundwater Protection } \\
\text { Management Program Plan }\end{array}$ & $5 / 9 / 90$ & annual/every 3 years \\
\hline $\begin{array}{l}\text { Waste Minimization } \\
\text { Pollution Prevention } \\
\text { Awareness Program Plan }\end{array}$ & $11 / 1 / 91$ & annualevery 3 years \\
\hline Environmental Monitoring Plan & $11 / 9 / 91$ & annualevery 3 years \\
\hline
\end{tabular}




\subsection{NOTIFICATION OF ENVIRONMENTAL OCCURRENCES}

Pursuant to DOE Orders 5400.1,5484.1, and 5000.3B, SNL/California, as a DOE-operating contractor, is responsible for appropriately reporting environmentally significant events.1,6,7 SNL/California will comply with the notification criteria contained in the DOE emergency preparedness orders (DOE Order 5500 series). Various Federal, State, and local laws and regulations also require $\mathrm{SNL} /$ California to report environmentally significant occurrences.

\subsection{Notification Procedures}

SNL/California has established procedures for notifying the DOE and appropriate regulatory agencies of environmental occurrences. The notification procedures are described below.

\subsubsection{SNL Line Organizations}

The line organizations have been instructed to report environmental incidents of any type to the ES\&H Hotline at SNL/California. The Occurrence Reporting Group of the Safety Department provides training in occurrence reporting procedures and responsibilities to all SNL/California employees and contractors.

\subsubsection{SNL/California ES\&H, Facilities and Security Center}

The Occurrence Reporting Program in the Safety Department at SNL/California is responsible for evaluating incidents and determining the appropriate level of notification. The ES\&H, Facilities and Security Center has developed and maintains the SNL/California Emergency Preparedness Plan. This plan includes "Emergency Plan Implementation Procedures," which address notification responsibilities. If necessary, the ES\&H, Facilities and Security Center will notify DOE/KAO, SNL/New Mexico organizations, and other agencies, as appropriate. Responsibility for notifying external agencies is discussed later in this section.

\subsubsection{DOE Kirtland Area Office}

$\mathrm{DOE} / \mathrm{KAO}$ is responsible for reporting events to the DOE/AL Emergency Operations Center (EOC). DOE/KAO acts as liaison between SNL/California and other Federal, State, and local agencies.

\subsubsection{DOE Albuquerque Operations Emergency Operations Center}

If necessary, the DOE/AL EOC will notify the DOE/HQ EOC, which will in turn, notify the appropriate Headquarter's Program Office and the Assistant Secretary for ES\&H. 


\subsubsection{Reporting Occurrences or Complaints After Working Hours}

If an event or condition requires immediate attention or emergency response, the employee involved is to call the Sandia emergency phone number, ext. 911. This extension connects to the Central Alarm System (CAS), which will dispatch the appropriate emergency response personnel. The CAS then notifies the appropriate Sandia Occurrence Management Representative (an OM Rep. is available 24 hours a day).

If an event or condition does not require emergency response, employees are to call the ES\&H hotline, ext. 4-ES\&H (4-3724), which is answered by the CAS after hours. The CAS will notify an OM Rep.

The OM Rep. determines if the event or condition is reportable under DOE Order 5000.3B.7 If it is, the OM Rep. notifies the appropriate facility manager, and the occurrence is reported to DOE/KAO, DOE/AL EOC, DOE/HQ (Assistant Secretary for Defense ProgramsDP-1), and SNL/New Mexico, as necessary. If it is not reportable per DOE 5000.3B, or if the call is a complaint rather than a report of an occurrence, the OM Rep. will follow up to see that appropriate action is taken to close out the issue.

\subsection{Notification Requirements}

DOE Orders clearly state that DOE operations will be conducted in full compliance with all applicable environmental laws and regulations. SNL/California is committed to this policy. Proper communication is a vital component of this commitment. SNL/California has policies and procedures to ensure proper and timely notification of environmental occurrences.

Operations at SNL/California are regulated under a wide range of environmental statutes. The type and magnitude of an environmental occurrence dictates which agencies are to be notified. Agencies potentially involved in emergency notification include:

- Lead DOE Agency

- National Response Center

- Office of Emergency Services

- U.S. EPA

- California EPA (Cal-EPA)

- U.S. Coast Guard

- U.S. Department of Transportation (highway spills)

- San Francisco Bay Area Regional Water Quality Control Board (RWQCB)

- Bay Area Air Quality Management District (BAAQMD)

- Alameda County

- City of Livermore

- California Department of Health Services (including AIP Program) 


\subsubsection{Department of Energy}

\section{General Requirements for Notification}

SNL/California will notify the DOE of significant environmental occurrences and significant "near misses" in accordance with the requirements of DOE Orders 5484.1 and 5000.3B.6,7 The ES\&H, Facilities and Security Center at SNL/California is responsible for appropriately notifying DOE/KAO. DOE/HQ will be notified through DOE/KAO. SNL/California will also concurrently notify DOE/KAO any time an environmental occurrence is reported to any outside agency.

DOE Order 5484.1 provides "Summary Charts for Accident Notification, Investigation, and Reporting." 6 This quick reference, as well as the complete guidance in the Order, will be used in determining the appropriate level of notification.

\section{Occurrence Reports}

Occurrence reports (ORs) are required for any off-normal or unplanned event having programmatic significance, such that it adversely affects or potentially affects performance, reliability, or safety of a facility. An example is a "near miss," a situation that could have resulted in an accident. The Occurrence Reporting Group is responsible for complying with the OR requirements described in DOE Order 5000.3B. ${ }^{7}$

Events or conditions significant enough to require an OR will be reported to the DOE in accordance with the time requirements specified in DOE Order 5000.3B. All reportable incidents require the facility manager to submit a written report to the DOE within 24 hours. Depending on the severity of the occurrence, oral notification to DOE/HQ and DOE/KAO may be required within 15 minutes to 2 hours of the incident.

\subsubsection{Environmental Protection Agency}

The EPA has established emergency notification requirements, which are published in Title 40, Code of Federal Regulations (CFR), Parts 112, 117 and 302 (CERCLA). 8 Under CERCLA, SNL/California (through the DOE) will report any hazardous pollutant release in excess of the reportable quantity to the National Response Center within 24 hours.

The EPA has established reportable quantities for specific chemicals and radionuclides. The SNL/California Environmental Protection and Environmental Operations departments are responsible for maintaining the list of reportable quantities. Line organizations are responsible for reporting all releases of one pint/one pound or more to Environmental Protection or Environmental Operations. One of these departments will evaluate all releases and determine the appropriate level of notification. An unplanned release that exceeds a reportable quantity must be reported to the National Response Center and to the DOE under the requirements of DOE Order 5000.3B. Personnel from Environmental Protection or Environmental Operations will immediately notify the Director, the Department Managers, and the OM Rep., who will ensure that the DOE is notified per DOE Order 5000.3B requirements. 


\subsubsection{State of California Bay Area Air Quality Management District}

SNL/California is required to notify the BAAQMD of any excess air emission or system failure, defined as:

- a failure of pollution abatement equipment resulting in an unplanned release to the atmosphere;

- an unplanned release to the atmosphere of a National Emission Standards for Hazardous Air Pollutants (NESHAPs) regulated material that exceeds the reportable quantity; ${ }^{9}$ or

- a violation of the requirements stated in any air discharge permit held by SNL/California.

An unplanned air release that requires reporting to the BAAQMD is reportable to the DOE under DOE Order 5000.3B requirements. The Air Quality Program staff of the Environmental Operations Department will notify the environmental department managers and the OM Rep., who will ensure that the DOE is notified.

\subsubsection{City of Livermore Water Reclamation Plant}

The Clean Water Act (CWA) establishes standards for industrial discharges to waterways and Publicly-owned Treatment Works (POTWs). SNL/California holds a discharge permit issued by the City of Livermore Water Reclamation Plant (LWRP). This permit requires SNL/California to notify the LWRP of any discharge that exceeds permit limits, including any release that may harm treatment plant operations.

The LWRP will be notified two ways:

1. If a release to the sanitary sewer system exceeds permit limits, the knowledgeable Environmental Operations Department engineer will immediately notify the responsible DOE/KAO staff member, who will notify the LWRP. If a DOE/KAO representative cannot be contacted, the SNL/California engineer will notify the LWRP directly.

2. Within 30 days, the SNL/California Environmental Operations Department will submit a written investigation report of the incident to $\mathrm{DOE} / \mathrm{KAO}$, which will be forwarded to the City of Livermore.

\subsection{Documentation of Environmental Occurrences}

\subsubsection{DOE Requirements}

Following an environmental occurrence, SNL/California will prepare a written report in accordance with the requirements of DOE Orders 5484.1 and 5000.3B.6,7 The appropriate facility manager is responsible for ensuring that the reports are electronically transmitted to the Occurrence Report and Processing System database. The appropriate ES\&H depart- 
ment at SNL/California is responsible for maintaining evidence files and copies of all reports. These reports will be made available to auditors and regulatory agencies.

\subsubsection{Annual Summary and Public Disclosure}

Environmental occurrences are summarized in the annual Site Environmental Report. 10 This report is made available to the DOE, regulatory agencies, and the general public.

\subsection{Effluent Information System Report}

The DOE Effluent Information System manages a database of radiological effluents released from DOE facilities. SNL/California measures and maintains records of radioactivity discharged in liquid and airborne effluent streams. As in the past, SNL/California will prepare the necessary radioactive effluent and on-site discharge data reports.

At the end of each calendar year, the Environmental Monitoring Program at SNL/California summarizes radiological emissions from the site. A DOE Form F-5821.1 is completed for each discharge point. The completed forms are submitted to DOE/KAO and, once approved, are forwarded to:

EG\&G Idaho, Inc.

Waste Management Program

Idaho Falls, ID 


\subsection{GENERAL PLANNING AND REPORTING}

\subsection{Long-range Environmental Protection Plan}

Chapter III of DOE Order 5400.1 requires that each field organization develop a long-range environmental protection plan. ${ }^{1}$ This plan should define specific environmental objectives. It should outline strategies for attaining those objectives, to include budgetary and staff resources, and a schedule for accomplishing established milestones.

SNL/California satisfies this requirement by providing information for the DOE's Environmental Restoration and Waste Management Five-Year Plan. ${ }^{11}$ This information is prepared by the Environmental Protection Department.

\subsection{Annual Site Environmental Report}

\subsubsection{Purpose}

DOE Orders 5400.1 and 5484.1 require each DOE site to prepare an annual summary environmental report.1,6 This report is prepared by the Environmental Operations Department and is approved by DOE/AL.

\subsubsection{Site Environmental Report Preparation}

Preparation of the annual environmental report is an ongoing process at SNL/California. Its format conforms to the requirements of Chapter II, Section 4 of DOE Order 5400.1.1 The Site Environmental Report documents all significant environmental activities throughout the year. ${ }^{10}$ It presents effluent and environmental monitoring data and discusses the Environmental Restoration Program and other environmental protection activities. Results of a radiological dose assessment, done to evaluate potential impacts on the general public, are included. The report also evaluates SNL/California's compliance records according to applicable environmental standards and includes a compliance summary section, which discusses any areas of noncompliance. The report's major emphasis is environmental management performance, which is evaluated by how well SNL/California's environmental protection activities comply with environmental laws and regulations. This section expresses Sandia's efforts to continually improve its corporate citizenship. In addition, Sandia works to make the document easy for the general public to understand.

\subsubsection{Site Environmental Report Format}

DOE Order 5400.1 establishes the scope and format for the site environmental report. Thus, the SNL/California's Site Environmental Report conforms to DOE Order 5400.1, Attachment II-1, "Suggested Content and Format for Annual Environmental: Reports." 


\subsubsection{Organizations Involved in Report Production}

Preparation of the Site Environmental Report is a cooperative effort among several organizations. The Environmental Operations Department holds overall responsibility for documenting all relevant environmental protection activities in the calendar year and using that information to produce the report. The final draft of the report is delivered to DOE/KAO according to a negotiated production schedule.

Off-site monitoring in the vicinity of SNL/California is conducted by LLNL's Environmental Monitoring Section (EMS). The EMS transmits the monitoring data to the SNL/California Environmental Operations Department for review and inclusion in the Site Environmental Report. The arrangement for environmental monitoring between SNL/California and LLNL is discussed further in Section 5.0.

Upon completion, the report is reviewed by SNL/California management. It is forwarded to DOE/KAO for further review and approval. Once the report has been approved, it is submitted to DOE/HQ.

\subsection{OMB Circular A-106}

The Environmental Protection Department updates the OMB Circular A-106 report semiannually as required by Executive Order 12088.5,12 It is submitted to DOE/HQ on December 15 and June 1 of each year. Environmental corrective actions and associated budgetary requirements are incorporated into the A-106 report using the guidance provided. Each discipline in the Environmental Protection Department is consulted to gather and analyze the data required for the A-106 report. As appropriate, other SNL/California organizations are consulted for additional input. The information in this report correlates with the information in the DOE's Five-Year Plan. ${ }^{11}$ 


\subsection{SPECIAL PROGRAMS AND PLANS}

\subsection{Groundwater Protection Management Program}

Under DOE Order 5400.1, SNL/California is required to establish a program for groundwater protection management. ${ }^{1}$ The Environmental Protection Department developed a Groundwater Protection Management Program Plan (GPMPP) in May $1990 .{ }^{13}$ The plan is reviewed annually and updated at a minimum of once every three years.

The Environmental Assessment and Restoration Group, which is in the Environmental Protection Department, is responsible for implementing the GPMPP. Funding is provided through the DOE's Office of Environmental Restoration and Waste Management. Funding for the Groundwater Protection Program is projected into a five-year, DOE-approved baseline budget. When programmatic requirements increase or deviate from the baseline, requests for funding changes are submitted to the DOE for approval.

To avoid duplication of effort, Sandia may use existing plans, permits, and other technical compliance documents, in whole or in part, to satisfy GPMPP requirements. These may include documents prepared to ensure compliance with environmental protection acts, to include the Safe Drinking Water Act (SDWA), RCRA, CERCLA, CWA, and local regulatory acts, such as the Porter-Cologne Water Quality Control Act and Safe Drinking Water and Toxic Enforcement Act (Prop. 65).

DOE Order 5400.1 requires completion of a groundwater monitoring plan to be included as part of the GPMPP. SNL/California's groundwater monitoring plan incorporates elements of the ongoing groundwater monitoring program developed to meet the requirements of the Environmental Restoration Program. This program is ongoing at SNL/California, in compliance with RWQCB Compliance Order 89-184.14

\subsection{Waste Minimization and Pollution Prevention Awareness Program}

The Environmental Protection Department completed a Waste Minimization and Pollution Prevention Awareness Program Plan in May 1991. ${ }^{15}$ DOE, EPA, and Cal-EPA guidance was used in developing this plan.

As part of the waste minimization effort, SNL/California has appointed a full-time waste minimization coordinator in the Environmental Protection Department. This person is responsible for coordinating site-wide waste minimization activities.

Sandia's Waste Minimization and Pollution Prevention Awareness Program is an organized, comprehensive, and continual effort to reduce waste generation and to eliminate or minimize pollutant releases to all environmental media from all aspects of Sandia's operations. These efforts offer increased protection of public health and the environment. They also yield the following benefits:

1. reduce waste management and compliance costs,

2. reduce resource usage,

3. improve product yields, 
4. reduce or eliminate inventories and the potential for releases of hazardous chemicals reportable under the Emergency Planning and Community Rightto-Know Act, and

5. reduce or eliminate the potential for civil and criminal liabilities under environmental laws.

The program reflects the goals and policies for waste minimization of this organization and represents an ongoing effort to make pollution prevention part of Sandia's operating philosophy. In accordance with the DOE policy, a hierarchical approach to waste reduction has been adopted and is applied to all types of waste.

The first principle of waste minimization is eliminating or minimizing waste generation through source reduction. If possible, waste materials that cannot be eliminated or minimized are used, reused and or recycled (i.e., reclaimed). As a last resort and to the greatest extent possible, all waste is treated to reduce volume, toxicity, or mobility before storage or disposal.

\subsubsection{Strategy}

The guidance and the regulatory requirements for waste minimization and pollution prevention at Sandia are documented in a formal Waste Minimization and Pollution Prevention Awareness Program Plan..$^{15}$ Site-specific implementation procedures have been developed. The procedures are designed to obtain accurate and current information on waste stream generation and waste management costs. This information provides the basis for implementing specific waste minimization techniques and technologies. The procedures include ways to collect information, evaluate options, and identify cost-effective waste minimization techniques. The essential elements of the strategy are to:

1. create an organization that comprises line and staff representatives who will develop and administer the waste minimization program,

2. define targets of waste to reduce, and

3. develop a method for tracking the performance and progress of the program.

The Waste Minimization and Pollution Prevention Awareness Program's objectives are to:

- foster a philosophy of conserving resources and creating a minimum of waste and pollution in achieving strategic objectives;

- promote the use of nonhazardous materials in operations to minimize the potential risks to human health and the environment;

- reduce or eliminate waste generation through product substitution, product reformulation, process modification, improved housekeeping, and on-site closed-loop reuse and recycling to minimize adverse effects on the air, water, and land;

- enhance communication of waste minimization objectives, goals, and ideas laterally and vertically among organizations; 
- characterize nonhazardous waste streams and develop a baseline of waste generation data;

- identify and implement methods and technologies for waste minimization;

- target policies, procedures, or practices that may inhibit waste minimization;

- create incentives for pollution prevention;

- develop and implement employee pollution prevention awareness programs;

- collect and exchange waste minimization information through technology transfer, outreach, and educational networks;

- develop means for fully disseminating technological information to site users;

- increase employee awareness of pollution prevention goals, objectives, and methods;

- develop specific goals and schedules for waste minimization activities; and

- comply with Federal and State regulations and DOE requirements for minimization.

\subsubsection{Organization and Staff Responsibilities}

A Pollution Prevention Team (P2 Team) has been created to oversee the implementation of the Waste Minimization and Pollution Prevention Awareness Program. Members of the P2 Team and their responsibilities are described below. The P2 Team has a project structure, i.e., representatives remain members of their own line organizations in a matrix-management system. The P2 Team comprises two chairs, site coordinators, representatives from line organizations, and support representatives and contractors, as needed.

\section{The P2 Team Chairs}

The P2 Team chairs-a representative from SNL/New Mexico and SNL/California-are responsible for the overall corporate Waste Minimization and Pollution Prevention Awareness Program.

\section{Program Site Coordinators}

The site coordinators are responsible for developing, directing, implementing, and documenting the Waste Minimization and Pollution Prevention Awareness Program.

\section{Line Organization P2 Team Representatives}

Line P2 Team representatives help line organizations plan, organize, and direct activities that will help them meet their waste minimization responsibilities. The line representatives also examine proposed new projects (with the assistance of project staff) for pollution prevention opportunities. They provide the critical interface between the line organizations and the waste minimization site coordinators. 


\section{Support Representatives}

Support representatives (from Purchasing, Property Management, Finance, Industrial Hygiene, Health Physics, Facilities, Public Relations, Safety, Training, and various other line organizations) are available to help the P2 Team as needed. These support personnel represent a resource to which the line representatives can turn for advice and assistance.

\section{Line Organizations}

Responsibility for waste minimization and pollution prevention rests with line organizations (waste generators). Line organizations are responsible for developing and maintaining detailed waste assessments, identifying pollution prevention opportunities, providing necessary information for waste characterization and certification, obtaining guidance on regulatory and waste management requirements from Environmental Protection Department personnel, and implementing pollution prevention strategies and technologies.

\section{Individuals}

All Sandians are responsible for:

- understanding the Waste Minimization and Pollution Prevention Awareness Program;

- practicing the concepts of pollution prevention in their activities; and

- informing the P2 Team of any anticipated new waste streams or changes in existing waste streams. 


\subsection{ENVIRONMENTAL MONITORING PROGRAM}

The Environmental Operations Department is responsible for the Environmental Monitoring Program. This program ensures that site operations comply with all Federal, State, and local regulations and DOE Orders regarding emissions to the environment. The Environmental Monitoring Group is responsible for monitoring the general environment of the Laboratory and vicinity. The monitoring data gathered are used to verify compliance with established environmental standards, to assess potential impacts to the public and the environment from site operations, and to ensure that site operations do not degrade the environment.

Environmental monitoring at SNL/California consists of three major parts:

- airborne and liquid effluent monitoring,

- meteorological monitoring, and

- environmental surveillance.

\subsection{Effluent Monitoring}

Effluent monitoring is the collection and analysis of samples or direct measurements of liquid and gaseous effluents for characterizing and quantifying contaminants released.

Airborne and liquid effluents are monitored to ensure compliance with established limits for release of pollutants into the atmosphere or bodies of water. At SNL/California, the pollutant of primary concern being released to the atmosphere is tritium from the Tritium Research Laboratory (TRL). Accordingly, the TRL stack is monitored continuously. The data are used to calculate potential doses to people off-site.

The only water pathways are discharges to the sanitary sewer system and surface runoff to the storm sewer system. The sanitary sewer effluent from SNL/California merges with the LLNL sewer effluent at the LLNL sewer outfall before they are discharged to the city sewer system. These pathways are monitored for pollutants that could possibly be released from site activities. Besides ensuring that release limits are not exceeded, these data are used as a warning system to ensure that pollutants are not released in concentrations sufficient to affect the operations at the LWRP. In case of such discharges, both LLNL and the LWRP are notified. Sandia discharges no process wastewater directly to the ground, arroyo, or any other surface water body.

\subsection{Environmental Surveillance}

Environmental surveillance involves the collection and analysis of samples of environmental media (e.g., air, water, soil, foodstuffs). It is conducted to verify that emission controls are effective in preserving the local environs, and to check for possible buildup of pollutants. It also provides the information needed to perform dose assessment calculations, which verify that SNL/California operations do not adversely affect the public. The potential radiological air emissions from SNL/California are tritium and depleted uranium. Potential pollutant emissions to the sanitary sewer or storm-water runoff collection system include tritium, metals, various organic compounds, solids, and minerals. 
Because the two DOE sites in Livermore (LLNL and SNL/California) are next to each other, distinguishing between their environmental impacts is frequently impossible. Therefore, SNL/California and LLNL have established a cooperative arrangement for environmental monitoring. (Note: LLNL is also a prime contractor, but is operated by the University of California and reports to the Oakland DOE Operations Office.) The two facilities have prepared and signed a "Joint Statement of Responsibilities for Environmental Monitoring at Livermore." 16 This statement documents each facility's roles and responsibilities for environmental monitoring. Each site monitors its own effluents and performs on-site surveillance. Because LLNL has facilities available for analyzing extremely low-level radiological samples, LLNL collects and processes most of the off-site environmental samples, and subsequently transmits the data to SNL/California. SNL/California supplements the LLNL surveillance system by doing site-specific surveillance (sewer monitoring, stack monitoring, groundwater monitoring, and perimeter external radiation surveillance).

Meteorological information representative of conditions at SNL/California is used for assessing the transport, diffusion, and deposition of materials released to the atmosphere by SNL/California operations. Sandia maintains a meteorological tower for collecting the required data. The Environmental Monitoring Group is responsible for meteorological maintenance, calibration, and data archiving.

\subsection{Environmental Monitoring Plan}

DOE Order 5400.1 requires each site using hazardous materials to prepare a site-specific environmental monitoring plan. 1 This plan is to document all aspects of effluent monitoring and environmental surveillance. It must include a thorough description of the monitoring program, rationale, design criteria, and quality assurance. SNL/California's Environmental Monitoring Plan has been prepared by the Environmental Operations Department. ${ }^{17}$ It was approved by DOE/AL on April 7, 1992. This plan is reviewed annually and updated at least every three years.

The Environmental Monitoring Plan describes all elements of the SNL/California Environmental Monitoring Program, as described above. The plan summarizes the regulatory requirements (DOE, Federal, State, and local) for monitoring, as well as SNL/California's compliance with these requirements.

The Environmental Monitoring Plan addresses four essential elements:

1. Radiological Monitoring. The plan addresses the requirements for radiological effluent monitoring and environmental surveillance contained in DOE Orders 5400.5 and DOE/EH-0173T. ${ }^{18,19}$ The plan also ensures compliance with the requirements of Title $40 \mathrm{CFR}$, Part 61 (NESHAPs), ${ }^{9}$ including an assessment of radiological impact to the public, done using EPA-approved methods.

2. Nonradiological Monitoring. The plan addresses environmental and effluent monitoring of nonradiological hazardous materials to ensure compliance with Federal, State, and local regulations. 
3. Meteorological Monitoring. Accurate meteorological data serve many purposes, such as directing environmental monitoring activities, radiological assessment, and emergency response. The meteorological system is part of the Atmospheric Release Advisory Capability (ARAC), a DOE-run network of meteorological stations designed to provide information to emergency response personnel in case of a release of radioactive or toxic materials. Meteorological instruments and supporting equipment conform to ARAC specifications. The Environmental Monitoring Plan describes the existing program for meteorological data acquisition. It also addresses instrument maintenance and calibration, and data management.

4. Groundwater Monitoring Program. SNL/California has a Groundwater Monitoring Program, as described in Section 4.1.

\subsubsection{Environmental Data Management}

Effluent and environmental monitoring data are collected to verify the effectiveness of pollution control measures and to assess the potential impact on the public and environment of operations at SNL/California. These activities also ensure compliance with all applicable environmental laws and regulations. The Environmental Monitoring Plan identifies the applicable regulations and the actions to demonstrate compliance.

SNL/California has established a database for tracking and archiving environmental data. This system manages field and analytical information generated by environmental monitoring, environmental restoration, and groundwater protection. The database is backed up daily. In addition, hard copies of the data are maintained by the responsible program for about one year. They are then transmitted to the ES\&H Records Center for retention.

The Environmental Operations and Environmental Protection departments are responsible for managing environmental data. Each year, these data are summarized in the Site Environmental Report (see Section 3.2).10 This report also summarizes SNL/California compliance with environmental laws and regulations.

SNL/California has developed a Quality Assurance Management Plan for the ES\&H, Facilities and Security Center (see Section 6.0). ${ }^{20}$ Specific procedures for data verification and management are incorporated in a Quality Assurance Project Plan and operational procedures for the Environmental Monitoring Program. ${ }^{21}$

Data management done by LLNL is covered by the Surveillance Monitoring Group's (formerly the Environmental Quality Verification Group) Quality Assurance Plan and Procedures Manual.22,23 These documents meet the requirements of ANSI/ASME NQA-1,24 the DOE, and the EPA for data analysis.

\subsubsection{Environmental Monitoring Plan Schedule}

In accordance with DOE Order 5400.1, all environmental monitoring requirements will be implemented within three years of the issuance of the Order. The plan was submitted to the DOE on April 7, 1992. It will be reviewed annually and updated at least every three 
years. If needed, additional budget and resources will be requested through the regular budgetary process.

\subsection{Environmental Monitoring Activities}

The Environmental Monitoring Program is conducted jointly by SNL/California and LLNL because the two sites are next to each other and have similar operations. LLNL conducts the majority of the off-site environmental monitoring. SNL/California augments this program by performing site-specific monitoring.

\subsubsection{Implementation}

Both LLNL personnel and the SNL/California Environmental Monitoring Group, in the Environmental Operations Department, examine the significant pathways by which contaminants can enter the environment. These pathways, from which samples are taken, include ambient air, surface water, soil, sewage, groundwater, storm-water runoff, vegetation, and local foodstuffs. An extensive network of environmental dosimeters also measures external radiation levels. SNL/California also monitors all potentially contaminated airborne and liquid effluents by:

1. measuring airborne tritium,

2. sampling storm-water runoff from the site,

3. sampling sanitary sewer effluents, and

4. monitoring external radiation at the site perimeter.

The Environmental Monitoring Program was thoroughly reviewed as part of the development of the Environmental Monitoring Plan. ${ }^{17}$ This plan identifies any needed changes to the existing monitoring and compliance activities. It is reviewed annually and updated every three years. The Environmental Operations Department is responsible for implementing the Environmental Monitoring Plan.

\subsubsection{Reporting}

Environmental monitoring data and compliance activities are published in the Site Environmental Report (see Section 3.2). ${ }^{10}$ It is sent to the DOE and appropriate regulatory agencies. It is also made available to the general public.

Radiological emissions from SNL/California are summarized for the calendar year and are reported to the DOE Effluent Information System (see Section 2.4).

The Environmental Operations Department is responsible for managing the environmental monitoring data and preparing the summary reports. 


\subsection{QUALITY ASSURANCE AND DATA VERIFICATION}

\subsection{Quality Assurance Program}

DOE Orders $5400.1^{1}$ and $5400.5^{18}$ require a quality assurance program for environmental monitoring that is consistent with DOE Order $5700.6 \mathrm{C} .{ }^{25}$ These requirements are implemented through the ES\&H, Facilities and Security Center's Quality Assurance Management Plan, which became effective April 23, 1991. This plan meets the requirements of DOE Order 5700.6C.25 ANSI/ASME NQA-1 1989 was used as the primary guidance for preparing this plan. ${ }^{24}$ The requirements of the Quality Assurance Management Plan are augmented through the use of implementing procedures, which dictate center-wide requirements, and operating procedures, which provide task-specific instructions.

The quality assurance elements of the SNL/California Environmental Monitoring Program are documented in the Program's Quality Assurance Project Plan. ${ }^{21}$ This plan implements the requirements of the Center's Quality Assurance Management Plan. ${ }^{20}$ It was prepared following the guidance of DOE Order 5700.6C and ANSI/ASQC-E4-19xx. ${ }^{25,26}$ It covers quality assurance guidelines of DOE/EH-0173T. ${ }^{19}$ The Quality Assurance Project Plan establishes program responsibilities to ensure data are accurate, complete, precise, and representative. ${ }^{21}$

The collection of environmental samples by LLNL's Environmental Monitoring Group is covered by the Environmental Quality Verification Group Quality Assurance Plan. ${ }^{22}$ This plan meets the requirements of DOE/EH-0173T,19 ANSI/ASME NQA-1,24 and EPA guidelines for the preparation of quality assurance program plans. The provisions of this plan have been implemented through the Environmental Monitoring Plan, Appendix B-Procedures. ${ }^{17}$

Environmental sample processing done by LLNL's Nuclear Chemistry Department is covered by the Radiological Analytical Services Laboratory Quality Assurance Project Plan. ${ }^{27}$ This plan also meets the requirements of DOE/EH-0173T, ${ }^{19}$ ANSI/ASME NQA- $1,{ }^{24}$ and EPA guidelines for preparing quality assurance program plans.

Contract laboratories doing analyses for LLNL and SNL/California's environmental monitoring program are accredited by the Cal-EPA. To receive accreditation, the laboratory must have an implemented quality assurance plan. Periodically, the Cal-EPA inspects accredited laboratories to make sure they are operating within quality assurance requirements.

\subsection{Laboratory Certification}

All environmental samples collected for regulatory compliance purposes are collected using guidance issued by the EPA. They are analyzed by off-site contract laboratories certified by the Cal-EPA. To assure that the laboratory is certified for the requested analysis, SNL/California uses the Cal-EPA semiannual report, which lists the specific analyses each laboratory is certified to perform. SNL/California permanently retains the analytical data and associated quality assurance documentation. 


\subsection{DOE Laboratory Quality Assurance Program for Radioactive Materials}

SNL/California performs in-house tritium analysis on a variety of samples, including some environmental samples. As an independent quality check, the on-site laboratory participates in a tritium analysis intercomparison study, which is conducted by the EPA Environmental Monitoring Systems Laboratory in Las Vegas.

LLNL conducts much of the off-site radiological environmental monitoring. LLNL's quality assurance procedures are documented in the Environmental Quality Verification Group Quality Assurance Plan.22 As part of this program, LLNL participates in intercomparison laboratory assessments sponsored by the EPA's Environmental Radioactivity Laboratory and the DOE Environmental Measurements Laboratory.

\subsection{Independent Data Verification}

"EH-1, in consultation with the appropriate Program Senior Official and field organization, shall develop an independent data verification program as part of environmental monitoring programs at DOE facilities." 1

The Laboratory Management Branch of the DOE Office of Technology Development has been established to provide technical support to all environmental analytical laboratory operations throughout the DOE. The Branch was also established to assist in developing quality assurance programs and implementing an independent data validation program. SNL is monitoring the progress of this DOE program, and when it is implemented, will participate in the program to ensure independent validation of environmental sampling data.

As noted, LLNL conducts the majority of the off-site environmental monitoring. LLNL addresses independent data verification in its quality assurance plan. At SNL/California, much of the environmental sampling and analysis is conducted by off-site contractors. These contractors are required to have a comprehensive quality assurance plan. The $Q A / Q C$ portion of the environmental monitoring program ensures valid and verifiable data. Additionally, SNL/California's Quality Assurance Project Plan for environmental monitoring addresses validation of data from LLNL and contract laboratories. ${ }^{21}$ It provides an integrated mechanism for implementing quality assurance for all facets of the environmental protection program. The Quality Assurance Project Plan uses guidance from the ES\&H, Facilities and Security Center's Quality Assurance Management Plan and implementing procedures to establish data quality objectives. ${ }^{20}$ 


\subsection{REFERENCES}

1. U. S. DOE, Order 5400.1, General Environmental Protection Program (November 1988).

2. U. S. DOE, Sandia National Laboratories, Environment, Safety, and Health Manual, SAND88-1161 (Updated 1993).

3. J. Russell, ALARA Program Implementation, Sandia National Laboratories/California, Implementing Procedure IP-25 (January 1993).

4. U. S. DOE, Order 5482.1B, Environment, Safety, and Health Appraisal Program (September 1986).

5. U. S. DOE, Sandia National Laboratories/California, OMB Circular A-106 Report (annual).

6. U. S. DOE, Order 5484.1, Chapter I, Environmental Protection, Safety, and Health Protection Information Reporting Requirements (1981).

7. U.S. DOE, Order 5000.3B, Occurrence Reporting and Processing of Operations Information (February 1992).

8. U. S. EPA, Title 40 CFR, Parts 112, 117 and 302 (1994).

9. U. S. EPA, Title 40 CFR, Part 61, National Emission Standards for Hazardous Air Pollutants (NESHAPs), Subpart H, "Standards for Radionuclides" (1994).

10. D.D. Brekke and R. C. Holland, Site Environmental Report for 1992, Sandia National Laboratories/ California, SAND93-8015 (October 1993).

11. U.S. DOE, Environmental Restoration and Waste Management Five-Year Flan (July 1990).

12. Executive Order 12088 (October 13, 1976).

13. U.S. DOE, Sandia National Laboratories/California, Groundwater Protection Management Program Plan (1992).

14. State of California, San Francisco Bay Region, Regional Water Quality Control Board, Order 89-184 (December 13, 1989).

15. U. S. DOE, Sandia National Laboratories/California, Pollution Prevention Plan (May 1994).

16. U. S. DOE, "Joint Statement of Responsibilities for Environmental Monitoring at Livermore," SNL/California and LLNL (August 1, 1993).

17. R. C. Holland, Environmental Monitoring Plan, Sandia National Laboratories/California, SAND91-8013 (June 1992).

18. U. S. DOE, Order 5400.5, Radiation Protection of the Public and the Environment (February 1990).

19. U. S. DOE, Environmental Regulatory Guide for Radiological Effluent Monitoring and Environmental Surveillance, DOE/EH-0173T (1991).

20. U. S. DOE, Sandia National Laboratories/California, Quality Assurance Management Plan (June 1993).

21. R. C. Holland, Quality Assurance Project Plan, Environmental Monitoring Program, Sandia National Laboratories/California, SAND93-8010 (June 1993).

22. R. C. Holland, Quality Assurance Plan, Environmental Quality Verification Group, Lawrence Livermore National Laboratory, UCAR-10203 (September 1987).

23. D. D. Brekke, M. G. Brown, T. M. Carlsen, and R. C. Holland, Procedures Manual, Environmental Quality Verification Group, Lawrence Livermore National Laboratory, UCAR-10254 (1988).

24. American Society of Mechanical Engineers, Quality Assurance Program Requirements for Nuclear Facilities, ANSI/ ASME NQA-1 (1986).

25. U. S. DOE, Order 5700.6C, Quality Assurance (August 1992).

26. American Society of Quality Control, Quality Assurance Program Requirements for Environmental Programs, ANSI/ASQC E4-19xx (Draft, 1991).

27. J. Merrigan, Quality Assurance Project Plan, Radiological Analytical Services Laboratory, Lawrence Livermore National Laboratory (1991). 


\section{ACRONYMS AND ABBREVIATIONS}

AIP

ALARA

ARAC

BAAQMD

Cal-EPA

CAS

CERCLA

CFR

CWA

DOE

DOE/AL

DOE/KAO

DOE/HQ

EMS

EOC

EPA

ES\&H

GPMPP

LAP

LLNL

LWRP

MSDS

NEPA

NESHAPs

OM Rep.

OR

POTWS

$Q A / Q C$

RCRA

RWQCB

SCEC

SDWA

SHEAC

SNL

SOPs

SQLC

TRL

WMSC
Agreement in Principle

As low as reasonably achievable

Atmospheric Release Advisory Capability

Bay Area Air Quality Management District

California Environmental Protection Agency

Central Alarm System

Comprehensive Environmental Response, Compensation, and Liability Act

Code of Federal Regulations

Clean Water Act

Department of Energy

DOE Albuquerque Operations Office

DOE Albuquerque Operations Office, Kirtland Area Office

DOE Headquarters (EH-1)

Environmental Monitoring Section (LLNL)

Emergency Operations Center

Environmental Protection Agency

Environment, Safety and Health

Groundwater Protection Management Program Plan

Laboratory Assessment Program

Lawrence Livermore National Laboratory

Livermore Water Reclamation Plant

Material Safety Data Sheet

National Environmental Policy Act

National Emission Standards for Hazardous Air Pollutants

Occurrence Management Representative

Occurrence Report

Publicly-owned Treatment Works

quality assurance/quality control

Resource Conservation and Recovery Act

Regional Water Quality Control Board

SNL/California ES\&H Council

Safe Drinking Water Act

Safety, Health, and Environment Appraisal Committee

Sandia National Laboratories

Safe Operating Procedures

SNL Quality Leadership Council

Tritium Research Laboratory

Waste Minimization Steering Committee 


\section{UNLIMITED RELEASE}

\section{INITIAL DISTRIBUTION}

U.S. Department of Energy (5)

Albuquerque Operations Office

Attn.: J. Andrews

K. Carlson

J. Johnsen

G. Laskar

S. E. Umshler

P.O. Box 5400

Albuquerque, NM 87115

MS0141, R. Park, Org. 11300

MS0141, T. Vandenberg, Org. 11300

MS1067, L. Jones, Org. 7000

MS1066, J. Baremore, Org. 7200

MS1065, R. Rohde, Org. 7254

MS1315, T. Blejwas, Org. 7500

MS1054, J. Stiegler, Org. 7700

MS1305, J. D. Fish, Org. 7574

MS1305, S. Hwang, Org. 7575

MS1309, Environmental Operations Programs Library, Org. 7512

MS9001, J. C. Crawford, Org. 8000

Attn.: E. E. Ives, 5200

J. B. Wright, 5300

M. E. John, 8100

R. J. Detry, 8200

W. J. McLean, 8300

L. A. Hiles, 8400

P. E. Brewer, 8500

R. C. Wayne, 8700

M. T. Dyer, 8800

D. L. Crawford, 8900

MS9021, K. W. Gordon, Org. 8535

MS9901, L. A. West, Org. 8600

MS9041, D. Putz, Org. 8609

MS9222, D. D. Brekke, Org. 8642 (50)

MS9022, Mail Distribution for OSTI, Org. 8533-1 (10)

MS9022, Mail Distribution (8533-1)/Technical Library, MS 0899, 13414

MS0899, Technical Library, Org. 13414 (4)

MS9018, Central Technical Files, Org. 8523-2 (3) 